Aim of the study: Breast cancer is the most common cause of death in women. Obesity has been associated with increased risk of breast cancer in post-menopausal women. It induces chronic inflammation, which increases local and systemic levels of cytokines and adipokines such as leptin. Leptin (LEP) and leptin receptor (LEPR) genes have several polymorphisms in humans. This study aims to assess the association between blood levels of leptin and LEPR Q223R gene polymorphism in patients of cancer breast. Material and methods: The current study was carried on 48 female breast cancer patients and 48 heathy female subjects. Carcinoembryonic antigen (CEA), cancer antibody CA15-3, and leptin hormone were determined. Single nucleotide polymorphism of LEPR Q223R was assessed by PCR/RFLP. Statistical analysis used: The statistical analysis of data was done by using SPSS version 20.

Results: There were significant in creases in the concentrations of CEA $(p=0.004)$, CA15-3 $(p<0.001)$, and leptin hormone $(p<0.001)$ in BC patients in relation to the respective concentrations in control subjects. CEA and CA 15-3 showed significant differences between various $B C$ stages. As regard to LEPR Q223R gene polymorphism, AA genotype showed significantly higher frequency in $B C$ patients when compared to their respective controls, with higher risk to develop BC.

Conclusions: Leptin hormone shows significantly higher concentrations in BC patients. As regard to LEPR Q223R gene polymorphism, AA genotype showed significantly higher frequency in $\mathrm{BC}$ patients.

Key words: leptin, leptin receptor LEPR Q223R gene polymorphism, breast cancer.

Contemp Oncol (Pozn) 2017; 21 (1): 42-47 DOI: https://doi.org/10.5114/wo.2017.66655

\section{Leptin receptor Q223R polymorphism in Egyptian female patients with breast cancer}

\author{
Mona Abo-Bakr El-Hussiny ${ }^{1}$, Mohmed Ali Atwa ${ }^{1}$, Waleed Elnahas Rashad ${ }^{2}$, \\ Dalia A. Shaheen ${ }^{3}$, Nora Marzouk Elkady ${ }^{1}$
}

'Department of Clinical Pathology, Faculty of Medicine, Mansoura University, Mansoura, Egypt

2Department of Surgical Oncology, Faculty of Medicine, Mansoura University, Mansoura, Egypt

${ }^{3}$ Department of Medical Biochemistry, Faculty of Medicine, Mansoura University, Mansoura, Egypt

\section{Introduction}

Breast cancer is the most common cause of death in women worldwide. It accounts for $14 \%$ of the total cancer deaths [1]. Some risk factors have been recognised, such as overweight and obesity, lifestyle, history of reproduction, steroid hormone managements, genetic factors, marital status, age at menarche, and oral contraceptives [2-5].

The relationship between obesity and risk of breast cancer depends greatly on menopausal status. In premenopausal women, obesity has been correlated with decreased risk of breast cancer, whereas it is associated with increased risk of breast cancer in post-menopausal women [6].

Obesity induces chronic inflammation, which increases local and systemic levels of cytokines such as tumour necrosis factor $\alpha$ (TNF- $\alpha$ ) and interleukin 6 (IL-6). Moreover, adipose tissue is now known as an endocrine organ, besides its function as a storage site of excess energy obtained from food intake. It produces adipokines (leptin and adiponectin), which also activate chronic inflammation [7].

Leptin (LEP), the obese (ob) gene product, is a 167 amino acids peptide hormone with proinflammatory functions. Its $\mathrm{N}$ terminal region is essential for the biological activities and binding to the receptor [8]. It plays an important role in the control of metabolism, immune processes, growth differentiation, and oxidation of lipids [9]. Leptin may inhibit proapoptosis signalling pathways and stimulate the growth of mammary tumour through several mechanisms, for example up-regulation of anti-apoptotic genes and down-regulation of apoptosis [10].

Leptin mediates its central and peripheral effects by leptin receptors (LEPR) present on the cell surface. It can bind to six isoforms of leptin receptors (obR a to f). These six isoforms belong to type I cytokine receptors family [11]. They contain a long isoform (obRb), which has full intracellular signalling, four short isoforms (OB-Rs) with less biological activity, and one secretory isoform [11-13].

Several single-nucleotide polymorphisms have been found in the leptin and leptin receptor genes in human. For example, an A that is substituted to $\mathrm{G}$ (at $\mathrm{nt}$ 668) leading to conversion of a glutamine to an arginine at codon 223 in exon 6 (Q223R) of the LEPR gene coding for the extracellular region in all isoforms of LEPR. This polymorphism affects the function of the receptor and changes its signalling capacity, which is linked to high levels of circulating leptin [14]. 
Numerous studies have confirmed the association of LEPR Q223R gene polymorphism with body mass index, insulin resistance, and postmenopausal breast cancer [15].

Hence, the present study aims to assess the effect of LEPR Q223R polymorphisms on breast cancer risk in Egyptian females, and their relation to different stages.

\section{Material and methods}

\section{Subjects}

This study was carried out on two groups. The first patient group comprised of 48 breast cancer females (mean age $47.7 \pm 7.5$ years; mean BMI $34.37 \pm 6.08 \mathrm{~kg} / \mathrm{m}^{2}$ ) who were selected from the Oncology Centre (MUOC) at Mansoura University through 2014-2015. Informed consent was obtained from all individuals included in the study. Approval of the Local Ethics Committee of Mansoura University was obtained, with reference code MS/190.

The second control group consisted of 48 heathy subjects (mean age $43.5 \pm 9.2$ years; mean BMI $27.28 \pm 3.52 \mathrm{~kg}$ / $\mathrm{m}^{2}$ ) with no family or personal history of cancer breast.

Subjects with non-adenocarcinoma epithelial tumours, non-epithelial tumours, Li fraumeni syndrome, or a history of ionising irradiation were excluded.

\section{Methods}

Five millilitres of peripheral blood was collected from the antecubital vein of overnight fasted patients. Then $1 \mathrm{ml}$ peripheral blood was collected in EDTA vacutainer tube from patients and controls for DNA extraction and restriction fragment length polymorphism (RFLP). $4 \mathrm{ml}$ blood was added to polypropylene tubes with a stopper, left to clot for 20 minutes, and the resulting serum was further divided into three aliquots. The aliquots were kept at $-20^{\circ} \mathrm{C}$ for other laboratory tests.

Liver function tests (SGPT, SGOT, albumin, and bilirubin) and kidney function tests (creatinine) were assessed spectrophotometrically using COBAS Integra 400 plus Roche Diagnostics Ltd. CH-6343 Rotkreuz Switzerland. Cholesterol was estimated by CHOD-POD liquid [16], triglycerides by GPO-POD liquid [17], and HDL by precipitating reagent [18]; all were supplied by SPINREACT,S.A./S.A.U. SPAIN. Indirect measurement of LDL cholesterol was performed using the Friedewald equation:

LDL-c $(\mathrm{mg} / \mathrm{dl})=\mathrm{TC}(\mathrm{mg} / \mathrm{dl})-\mathrm{HDL}-\mathrm{c}(\mathrm{mg} / \mathrm{dl})-\mathrm{TG}(\mathrm{mg} /$ dl) / 5 [19].

The carcinoembryonic antigen (CEA) and cancer antigen 15-3 (CA15-3) were estimated by electrochemiluminescence immunoassay (ECLIA) using ELECSYS 2010 Roch Diagnostics, Germany. Leptin hormone was estimated by sandwich ELISA technique using DBC Leptin ELISA, Diagnostics Biochem Canada Inc., cat. No. CAN-L-4260 [20].

\section{PCR-RFLP}

DNA was extracted from whole blood samples by G-spin ${ }^{\text {TM }}$ Total DNA Extraction Minikit (Intron biotechnology, www.intronbio.com). LEPR Q223R gene polymorphism was determined by PCR-RFLP (polymerase chain reaction restriction fragment length polymorphism).
For amplification of the region Gln223Arg polymorphism, the following primer was used: forward primer, 5-d ACCC TTT AAG CTG GGT GTC CCAAATGA-3; reverse primer,5-d CTA GCAAATA TTTTT GTAA GCAA TT -3. PCR amplification was done using DreamTaq PCR Green Master Mix (2X) (cat. No. k1081, Lithuania, EU). DreamTaq PCR Master Mix (2X) was gently vortexed and briefly centrifuged after thawing. The reaction mixture of total volume $(25 \mu \mathrm{l})$ contained $15 \mu \mathrm{l}$ PCR Master Mix, $0.5 \mu \mathrm{l}$ forward primer (100 pmol), $0.5 \mu$ reverse primer (100 pmol), $5.0 \mu \mathrm{l}$ extracted DNA (100 ng), and $4 \mu \mathrm{l}$ nuclease-free water. The samples were gently vortexed and PCR was done using the thermal cycle (Biorad PTC-100 peltier, USA) [21].

The reaction mixture was heated to $94^{\circ} \mathrm{C}$ for five minutes, followed by 30 cycles each consisting of 60 seconds at $94^{\circ} \mathrm{C}$ (denaturation), 60 seconds at $55^{\circ} \mathrm{C}$ (annealing), 60 seconds at $72^{\circ} \mathrm{C}$ (extension), and a final seven-minute extension at $72^{\circ} \mathrm{C}$.

The PCR product was digested with Mspl (Thermoscientific Fast Digest, cat. No. FD 0014, Lithuania) [21]. The reaction mixture of total volume $(50 \mu \mathrm{l})$ contained $23 \mu \mathrm{lnu}$ clease-free water (\#R0581), $15 \mu$ l buffer, $10 \mu \mathrm{l}$ PCR product, and $2 \mu \mathrm{l}$ Mspl restriction enzyme. The components were incubated at $37^{\circ} \mathrm{C}$ for five minutes. The digested products were separated by electrophoresis in $2 \%$ agarose gels with ethidium bromide. The PCR product ( $440 \mathrm{bp}$ ) with G allele was digested by Mspl to two fragments (300 and $140 \mathrm{bp}$ ), whereas the PCR product with A allele could not be digested and yielded one fragment at $440 \mathrm{bp}$. So the homozygous GG giave two bands at 300 and 140 bp, homozygous AA giave one band at $440 \mathrm{bp}$, and the heterozygous GA gave three bands at 440,300, and $140 \mathrm{bp}$.

Lanes 1, 3, 5 represent AA genotypes (440 bp), lanes $2,6,7$, and 9 represent GA genotypes (440,300, and 140 bp), and lanes 4 and 8 represent GG genotype (300 and 140 bp) (Fig. 1).

\section{Statistical analysis}

Excel (Microsoft Office 2013) and SPSS version 20 (statistical package for social science) (SPSS, Inc., Chicago, IL) were used for statistical analysis. The $\chi^{2}$ test was used for assessing differences from Hardy-Weinberg equilibrium expectations. The associations between breast cancer and leptin receptor Q223R polymorphism were measured by odds ratio and their 95\% confidence interval. N.B: $p \leq 0.05$ is significant at confidence interval $95 \%$.

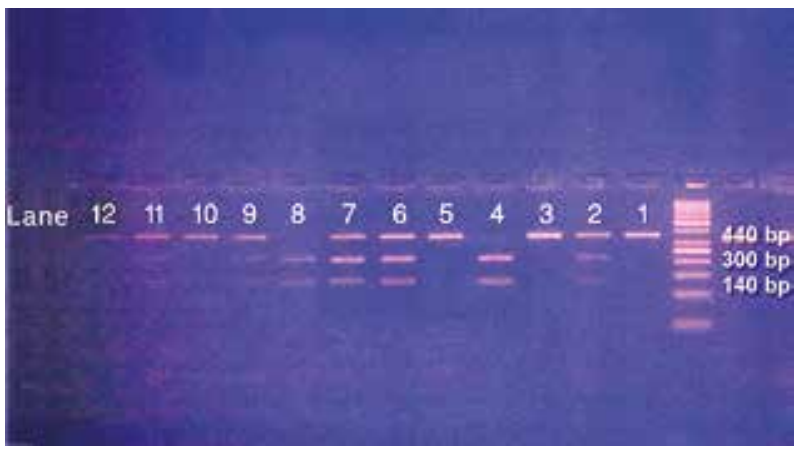

Fig. 1. PCR-RFLP with Mspl restriction enzyme 
Table 1. Lipogram, CEA, CA15-3, and leptin hormone concentrations in all studied groups

\begin{tabular}{|c|c|c|c|c|c|}
\hline \multirow[t]{2}{*}{ Parameter } & \multicolumn{2}{|c|}{$\begin{array}{l}\text { Control } \\
(n=48)\end{array}$} & \multicolumn{2}{|c|}{$\begin{array}{c}\text { BC Patients } \\
(n=48)\end{array}$} & \multirow[t]{2}{*}{$p$} \\
\hline & Median & Range & Median & Range & \\
\hline Cholesterol (mg/dl) & 154 & $112-259$ & 203 & $98-384$ & $0.004^{*}$ \\
\hline Triglycerides (mg/dl) & 93.5 & $49-290$ & 152 & $48-348$ & $0.003^{*}$ \\
\hline $\mathrm{HDL}(\mathrm{mg} / \mathrm{dl})$ & 39.5 & $34-45$ & 39 & $32-47$ & 0.985 \\
\hline $\mathrm{LDL}(\mathrm{mg} / \mathrm{dl})$ & 98.5 & 64-204 & 131 & $64-247$ & $0.006^{*}$ \\
\hline CEA (ng/ml) & 0.69 & $0.3-1.8$ & 1.75 & $0.4-9.3$ & $0.004^{*}$ \\
\hline CA 15-3 (U/ml) & 7.38 & $5.3-13.4$ & 19.045 & $5-261.5$ & $<0.001^{\star}$ \\
\hline Leptin hormone (ng/ml) & 54.15 & $30.4-67.8$ & 121.3 & $30.3-202.8$ & $<0.001^{\star}$ \\
\hline
\end{tabular}

Table 2. Comparison between various BC stages regarding CEA, CA 15-3, and leptin hormone concentrations

\begin{tabular}{|c|c|c|c|c|c|c|c|c|c|c|c|c|c|}
\hline \multirow{4}{*}{$\begin{array}{l}\text { Parameter } \\
\text { CEA (ng/ml) }\end{array}$} & \multicolumn{12}{|c|}{ BC Patients $(n=48)$} & \multirow{4}{*}{$\begin{array}{c}p \\
0.002^{*}\end{array}$} \\
\hline & \multicolumn{3}{|c|}{ Stage I $(n=12)$} & \multicolumn{3}{|c|}{ Stage II $(n=12)$} & \multicolumn{3}{|c|}{ Stage III $(n=12)$} & \multicolumn{3}{|c|}{ Stage IV $(n=12)$} & \\
\hline & \multirow{2}{*}{$\begin{array}{c}\text { Median } \\
0.815\end{array}$} & \multicolumn{2}{|c|}{ Range } & \multirow{2}{*}{$\begin{array}{c}\text { Median } \\
1.1\end{array}$} & \multicolumn{2}{|c|}{ Range } & \multirow{2}{*}{$\begin{array}{c}\text { Median } \\
1.8\end{array}$} & \multicolumn{2}{|c|}{ Range } & \multirow{2}{*}{$\begin{array}{c}\text { Median } \\
5.2\end{array}$} & \multicolumn{2}{|c|}{ Range } & \\
\hline & & 0.6 & 5.1 & & 0.4 & 4.8 & & 0.5 & 7.1 & & 0.5 & 9.3 & \\
\hline CA 15-3 (U/ml) & 16.935 & 8.7 & 45.5 & 13.115 & 5 & 21.8 & 19.215 & 6.8 & 52.0 & 40.5 & 15.3 & 261.5 & $0.003^{*}$ \\
\hline $\begin{array}{l}\text { Leptin hormone } \\
(\mathrm{ng} / \mathrm{ml})\end{array}$ & 121.3 & 54.1 & 150.4 & 114.5 & 90 & 175.6 & 112.25 & 76.1 & 201 & 154.3 & 30.3 & 202.8 & 0.325 \\
\hline
\end{tabular}

$P 1=$ comparison between stage I vs. stage $\|$

$P 2$ = comparison between stage I vs. stage III

P3 = comparison between stage I Vs. stage IV

$P 4$ = comparison between stage $/ /$ vs. stage III

P5 = comparison between stage II vs. stage IV

$P 6=$ comparison between stage III Vs. stage IV

CEA: $(P 1=0.729, P 2=0.106, P 3=0.002, P 4=0.073, P 5=0.002, P 6=0.003)$

CA15-3: $(P 1=0.184, P 2=0.707, P 3=0.009, P 4=0.106, P 5=0.001, P 6=0.043)$

Leptin: $(P 1=0.260, P 2=0.386, P 3=0.043, P 4=1, P 5=0.386, P 6=0.686)$

Table 3. Distribution of Leptin Receptor Q223R (alleles and genotypes) in BC patients and healthy control subjects

\begin{tabular}{|c|c|c|c|c|c|c|c|c|c|}
\hline \multirow[t]{2}{*}{ Parameter } & & \multicolumn{2}{|c|}{$\begin{array}{l}\text { Control } \\
(n=48)\end{array}$} & \multicolumn{2}{|c|}{$\begin{array}{l}\text { BC Patients } \\
(n=48)\end{array}$} & \multirow[t]{2}{*}{$p$} & \multirow[t]{2}{*}{ OR } & \multicolumn{2}{|c|}{$95 \% \mathrm{Cl}$} \\
\hline & & $n$ & $\%$ & $n$ & $\%$ & & & & \\
\hline \multirow[t]{3}{*}{ Genotypes } & $\mathrm{AA}$ & 2 & 4.2 & 9 & 18.8 & $0.025^{\star}$ & 5.308 & 1.082 & 26.040 \\
\hline & $A G$ & 24 & 50.0 & 15 & 31.3 & 0.061 & 0.455 & 0.198 & 1.045 \\
\hline & $\mathrm{GG}$ & 22 & 45.8 & 24 & 50.0 & 0.683 & 1.182 & 0.530 & 2.634 \\
\hline \multirow[t]{2}{*}{ Alleles } & A & 28 & 29.2 & 33 & 34.4 & 0.438 & 0.786 & 0.427 & 1.446 \\
\hline & G & 68 & 70.8 & 63 & 65.6 & & & & \\
\hline
\end{tabular}

\section{Results}

Serum cholesterol, triglycerides, and LDL-cholesterol showed significantly higher concentrations in breast cancer patients when compared to control subjects $(0.004$, $0.003,0.006$, respectively). There were significant increases in the concentrations of CEA ( $p=0.004)$, CA15-3 ( $p<$ $0.001)$, and leptin hormone $(p<0.001)$ in BC patients in relation to their concentrations in control subjects (Table 1).

CEA and CA 15-3 showed significant differences between various BC stages; this significance was attributed to significant increases in CEA and CA15-3 in stage IV when compared to stage I ( $p=0.002,0.009$, respectively); stage II $(p=0.002,0.001$, respectively), and stage $\mathrm{II}(p=0.003$, 0.043 , respectively) (Table 2 ).

AA genotype showed significantly higher frequency in $\mathrm{BC}$ patients when compared to control subjects, with higher risk of developing $\mathrm{BC}(p=0.025, \mathrm{OR}=5.308,95 \% \mathrm{Cl}$ : 1.082-26.040). As regard to $A G, G G$ genotypes, and $A, G$ alleles, there were no significant differences in frequency between breast cancer patients and controls without risk of breast cancer (Table 3). 
Table 4. Distribution of Leptin Receptor Q223R (alleles and genotypes) in BC patients according to stages

\begin{tabular}{|c|c|c|c|c|c|c|c|c|c|}
\hline \multirow[t]{2}{*}{ Parameter } & & \multicolumn{2}{|c|}{$\begin{array}{l}\text { BC stage I and II } \\
\quad(n=24)\end{array}$} & \multicolumn{2}{|c|}{$\begin{array}{l}\text { BC stage III and VI } \\
(n=24)\end{array}$} & \multirow[t]{2}{*}{$p$} & \multirow[t]{2}{*}{ OR } & \multicolumn{2}{|c|}{$95 \% \mathrm{Cl}$} \\
\hline & & $n$ & $\%$ & $n$ & $\%$ & & & & \\
\hline \multirow[t]{3}{*}{ Genotypes } & AA & 7 & 29.2 & 2 & 8.3 & 0.137 & 0.221 & 0.041 & 1.201 \\
\hline & $A G$ & 5 & 20.8 & 10 & 41.7 & 0.119 & 2.714 & 0.757 & 9.727 \\
\hline & GG & 12 & 50.0 & 12 & 50.0 & 1 & 1 & 0.323 & 3.101 \\
\hline \multirow[t]{2}{*}{ Alleles } & A & 19 & 39.6 & 14 & 29.2 & 0.283 & 1.591 & 0.680 & 3.722 \\
\hline & G & 29 & 60.4 & 34 & 70.8 & & & & \\
\hline
\end{tabular}

Table 5. Comparison of BC pathological types between different Leptin Receptor Q223R genotypes in all studied groups

\begin{tabular}{|c|c|c|c|c|c|c|c|}
\hline \multirow[t]{3}{*}{ Parameter } & \multicolumn{6}{|c|}{$\begin{array}{c}\text { BC patients } \\
(n=48)\end{array}$} & \multirow[t]{3}{*}{$p$} \\
\hline & \multicolumn{2}{|c|}{$\begin{array}{c}\text { AA } \\
(n=9)\end{array}$} & \multicolumn{2}{|c|}{$\begin{array}{c}\text { AG } \\
(n=15)\end{array}$} & \multicolumn{2}{|c|}{$\begin{array}{c}\text { GG } \\
(n=24)\end{array}$} & \\
\hline & $n$ & $\%$ & $n$ & $\%$ & $n$ & $\%$ & \\
\hline IDC & 6 & 66.7 & 9 & 60.0 & 14 & 58.3 & \multirow{3}{*}{$0.009^{*}$} \\
\hline ILC & 3 & 33.3 & 5 & 33.3 & 1 & 4.2 & \\
\hline Paget's disease & 0 & 0 & 1 & 6.7 & 9 & 37.5 & \\
\hline
\end{tabular}

IDC - invasive ductal carcinoma; ILC - invasive lobular carcinoma

More advanced BC stages (stage III and IV) showed no significant change in frequency in leptin receptor Q223R genotypes and alleles when compared to stage I and II (Table 4).

There was significant association between BC pathologic types and leptin receptor Q223R genotypes ( $p=$ 0.009) because the frequency of GG leptin receptor Q223R genotype was significantly high in Paget disease (Table 5).

\section{Discussion}

Breast cancer is the most common cause of death in women. It accounts for $14 \%$ of the total cancer deaths [1].

Obesity is associated with a high incidence of many serious diseases, including cancer [22]. Obesity due to lifestyles and unhealthy diets raises the risk of cancer, and it is predicted as a bad prognostic factor among survivors of breast cancer. Many studies reported that obesity is accompanied with high death rates from all cancers [23] However, the mechanism by which obesity can develop breast cancer remains unclear [24, 25].

In the present study cholesterol, triglycerides, and LDL-cholesterol showed significantly higher concentrations in breast cancer patients when compared to controls (Table 1). These findings are in accordance with Abdelsalam et al. [26] and Florenza et al. [27], who found that lipid profiles were increased significantly in all stages of breast cancer.

Leptin reduces body overweight and decreases the obesity rate as it regulates appetite and size of adipose tissue [28]. Although obese individuals have high levels of plasmatic leptin, they cannot control appetite as a result of development of non-responsive hypothalamic stage for the regulation of appetite and energy expenditure [29].
In the present study leptin hormone showed significantly higher concentrations in BC patients when compared to control subjects $(p<0.001)$. Conversely, leptin hormone did not show significant differences between various BC stages. These findings are concordant with the findings of Cleary et al. [30]; Tessitore et al. [31]; Han et al. [32]; Chen et al. [33]; Hou et al. [34]; Liu et al. [35] and Taaban et al. [36], who reported that the serum levels of leptin were significantly higher in breast cancer patients than in controls. This can be explained by the fact that the main component of human breast is adipose tissue, which is the chief site of leptin secretion. It has been reported that leptin has a role in mammary glands development [37]. In addition, cancerous cells present in the mammary gland overexpress $O B-R$ and respond to leptin stimulus by increasing vascular endothelial growth factor and its receptor 2, proliferation, and survival [38-40].

However Mantzoros et al. [41], Coskun et al. [42], Sauter et al. [43], Stattin et al. [44] and Woo et al. [45] reported that there was no relationship between breast cancer and serum leptin levels in postmenopausal women. This conflict can be explained by the failure of control of some potential factors, such as food intake, which affect leptin concentrations.

In the present study CEA showed significantly higher concentrations in breast cancer patients when compared to controls $(p=0.004)$ (Table 1$)$. This finding is in acordance with the results of Samy et al. [46], who found that preoperative serum levels of CA15-3 and CEA were significantly higher in breast cancer patients compared with the levels of the control group, and these markers decreased after operation.

In the present study CA15-3 showed significantly higher concentrations in breast cancer patients in comparison to control subjects $(p<0.001)$ (Table 1$)$; also, CEA and CA 15-3 
showed significant differences between various BC stages. This significance was attributed to significant increases in CEA and CA15-3 in stage IV when compared to stage I ( $p=$ $0.002,0.009$, respectively), stage $I I(p=0.002,0.001$, respectively), and stage III ( $p=0.003,0.043$, respectively), This is in agreement with Hashim [47], who reported increased levels of CA15-3 in breast cancer patients, when compared to women with benign tumours and healthy controls, and this increase is associated with advanced stages.

Paracchini et al. [48] demonstrated that a specific phenotype characterised by morbid obesity was produced due to genetic mutations in the leptin gene and the LEPR gene. Several polymorphisms related to an obese phenotype have been recognised in humans in the leptin and LEPR gene [49].

In the present study, the frequency of AA genotype of LEPR gene Gln223Arg polymorphisms was significantly high in BC patients when compared to controls $(p=0.025)$.

In agreement with our results, Snoussi et al. [50] and Anuradha et al. [51] reported that increased risk and poor prognosis of breast carcinoma are associated with leptin and LEPR polymorphisms. Also, Han et al. [21] described that the GA/AA genotypes of the LEPR gene (Gln223Arg) in combination with elevated lipids and leptin play a major role in the progression of breast cancer.

In contrast to our results, some researchers confirmed no association between GIn223Arg polymorphisms in the LEPR gene and breast cancer [52]. These differences may be attributed to gene-gene interaction, racial differences, and environmental factors. Also, changes in environmental temperature and stress can affect the expression of leptin [53] and change the risk of breast cancer.

Moreover, no significant differences were found between different leptin receptor Q223R genotypes in BC stages ( $p>0.05$ for each).

The frequency of Leptin Receptor Q223R genotypes and pathologic parameters (ER, PR, HER2, cancers stage) in breast cancer patients were not significantly associated [54], although our study shows significant association between breast cancer pathologic types and leptin receptor Q223R genotypes $(p=0.009)$. This is because the frequency of GG leptin receptor Q223R genotype was significantly high in Paget disease. Snoussi et al. [50] found that the LEPR 223G allele is accompanied by short survival and bad prognosis in breast cancer.

One limitation of our study is the higher BMI in patients than in controls, which may influence the leptin level, in addition to the role of cancer.

In conclusion, leptin hormone shows significantly higher concentrations in breast cancer patients when compared to controls. It did not show significant differences between various breast cancer stages. As regard to LEPR Q223R gene polymorphism, AA genotype frequency was significantly high in breast cancer patients when compared to controls, with higher risk of developing breast cancer. Otherwise, other genotypes and alleles show no significant differences between breast cancer patients and controls with no risk of breast cancer.
Source of support: Oncology Center (MUOC) at Mansoura University.

The authors declare no not conflicts of interest.

\section{References}

1. Jemal A, Center MM, Desantis C, Ward EM. Global patterns of cancer incidence and mortality rates and trends. Cancer Epidemiol Biomarkers Prev 2010; 19: 1893-907.

2. Berclaz G, Li S, Price KN, et al. Body mass index as a prognostic feature in operable breast cancer: the international breast cancer study group experience. Ann Oncol 2004; 15: 875-84

3. Asseryanis E, Ruecklinger E, Hellan M, Kubista E, Singer CF. Breast cancer size in postmenopausal women is correlated with body mass index and androgen serum levels. Gynecol Endocrinol 2004; 18: 29-36.

4. Lorincz AM, Sukumar S. Molecular links between obesity and breast cancer. Endocr Relat Cancer 2006; 13: 279-92.

5. Cao H, Yang ZH, Jiang JQ. Expression and clinical significance of activating transcription factor 3 in human breast cancer. Iran J Basic Med Sci 2013; 16: 1151-4

6. La Vecchia C, Giordano SH, Hortobagyi GN, Chabner B. Overweight, obesity, diabetes, and risk of breast cancer: interlocking pieces of the puzzle. Oncologist 2011; 16: 726-9.

7. Halberg N, Wernstedt-Asterholm I, Scherer PE. The adipocyte as an endocrine cell. Endocrinol Metab Clin North Am 2008; 37: 753-68.

8. Imagawa K, Numata Y, Katsuura G, et al. Structure-function studies of human leptin. J Biol Chem 1998; 273: 35245-9.

9. Markowska A, Malendowicz K, Drews K. The role of leptin in breast cancer. Eur J Gynaecol Oncol 2004; 25: 192-4.

10. Jarde T, Perrier SM, Vasson P, Caldefie-Chezet F. Molecular mechanisms of leptin and adiponectin in breast cancer. Eur J Cancer 2011; 47: 33-43.

11. Tartaglia LA. The leptin receptor. J Biol Chem 1997; 272: 6093-6.

12. Lee GH, Proenca R, Montez JM, Carroll KM, Darvishzadeh JG, Lee JI, Friedman JM. Abnormal splicing of the leptin receptor in diabetic mice. Nature 1996; 379: 632-5.

13. Zabeau L, Lavens D, Peelman F, Eyckerman S, Vandekerckhove J, Tavernier J. The ins and outs of leptin receptor activation. FEBS Lett 2003; 546: 45-50.

14. Howard JM, Beddy P, Ennis D, Keogan M, Pidgeon GP, Reynolds JV. Associations between leptin, adiponectin receptor upregulation, visceral obesity and tumour stage in oesophageal and junctional adenocarcinoma. Br J Surg 2010; 97: 1020-7.

15. Snoussi K, Strosberg AD, Bouaounia N, Ben Ahmed S, Helal AN, Chouchane L. Leptin and leptin receptor polymorphisms are associated with increased risk and poor prognosis of breast carcinoma. BMC Cancer 2006; 6: 38 .

16. Meiattini F, Prencipe L, Bardelli F, Giannini G, Tarli P. The 4-hydroxybenzoate/4-aminophenazone Chromogenic System. Clin Chem 1978; 24: 2161-5.

17. Buccolo G, David H. Quantitative determination of serum triglycerides by use of enzymes. Clin Chem 1973; 19: 476-482.

18. Grove TH. Effect of reagent $\mathrm{pH}$ on Determination of HDL Cholesterol by precipitation with Sodium Phosphotungstate-magnesium. Clin Chem 1979; 25: 560.

19. Friedewald WT, Levy RI, Fredrickson DS. Estimation of the concentration of low-density lipoprotein cholesterol in plasma, without use of the preparative ultracentrifuge. Clin Chem 1972; 18: 499 502.

20. Wiesner G, Vaz M, Collier G, Seals D, Kaye D, Jennings G, Lambert G, Wilkinson D, Esler M. Leptin is released from the human brain: influence of adiposity and gender. J Clin Endocrinol Metab 1999; 84: 2270-4.

21. Han CZ, Du LL, Jing JX, Zhao XW, Tian FG, Liu XY, Zhang LJ. Associations among Lipids, Leptin, and Leptin Receptor Gene Gin223Arg Polymorphisms and Breast Cancer in China. Biol Trace Elem Res 2008; 126: 38-48. 
22. Renehan AG, Tyson M, Egger M, Heller RF, Zwahlen M. Bodymass index and incidence of cancer: a systematic review and meta-analysis of prospective observational studies. Lancet 2008; 371: 569-78.

23. Calle EE, Rodriguez C, Walker-Thurmond K, Thun MJ. Overweight, obesity, and mortality from cancer in a prospectively studied cohort of U.S. adults. N Engl J Med 2003; 348: 1625-38

24. Prieto-Hontoria PL, Perez-Matute P, Fernandez-Galilea M, Bus tos M, Martinez JA, MorenoAliaga MJ. Role of obesity-associated dysfunctional adipose tissue in cancer: a molecular nutrition approach. Biochim Biophys Acta 2011; 1807: 664-78.

25. Pi-Sunyer X, The medical risks of obesity. Postgrad Med 2009; 121: 21-33.

26. Abdelsalam KE, Hassan IK, Sadig IA. The role of developing breast cancer in alteration of serum lipid profile. J Res Med Sci 2012; 17 $562-5$

27. Florenza AM, Branchi A, Sommaviva D. Serum lipoprotein profile in patients with cancer. A comparison with non-cancer subjects. Int J Clin Lab Res 2000; 30: 141-5.

28. Williams KW, Scott MM, Elmquist JK. From observation to experimentation: leptin action in the mediobasal hypothalamus. Am J Clin Nutr 2009; 89: 985S-990S.

29. Gabriely I, Ma XH, Yang XM, Rossetti L, Barzilai N. Leptin resistance during aging is independent of fat mass. Diabetes 2002; 51: 1016-21.

30. Cleary MP, Phillip FC, Getzin SC, et al, Genetically obese MMTVTGF-alph/Lep (ob) Lep (ob) female mice do not develop mammary tumors. Breast Cancer Res Treat 2003; 77: 205-15.

31. Tessitore L, Vizio B, Pesola D, Cecchini F, Mussa A, Argiles JM, Benedetto C. Adipocyte expression and circulating levels of leptin increase in both gynaecological and breast cancer patients. Int J Oncol 2004; 24: 1529-35.

32. Han C, Zhang HT, Du L, Liu X, Jing J, Zhao X, Yang X, Tian B. Serum levels of leptin, insulin, and lipids in relation to breast cancer in China. Endocrine 2005; 26: 19-24.

33. Chen DC, Chung YF, Yeh YT, Chaung HC, Kuo FC, Fu OY, Chen HY, Hou MF, Yuan SF. Serum adiponectin and leptin levels in Taiwanese breast cancer patients. Cancer Lett 2006; 237: 109-14.

34. Hou WK, Xu YX, Yu T, Zhang L, Zhang WW, Fu CL, Sun Y, Wu O, Chen L. Adipocytokines and breast cancer risk. Chin Med J 2007; 120: 1592-6.

35. Liu CL, Chang YC, Cheng SP, Chern SR, Yang TL, Lee JJ, Guo IC, Chen CP. The roles of serum leptin concentration and polymorphism in leptin receptor gene at codon 109 in breast cancer. Oncology 2007; 72: 75-81

36. Taaban DF, Eman S. Saleh ES, Hashim ZM. Zuhair B. Kamal ZB. Association of serum adiponectin and leptin levels with breast cancer in Iraqi women. Am J Pharmacol Sci 2014; 2: 103-9.

37. Hu X, Juneja SC, Maihle NJ, Cleary MP. Leptin - a growth factor in normal and malignant breast cells and for normal mammary gland development. J Natl Cancer Inst 2002; 94: 1704-11.

38. Ishikawa M, Kitayama J, Nagawa H. Enhanced expression of leptin and leptin receptor (OB-R) in human breast cancer. Clin Cancer Res 2004; 10: 4325-31.

39. Gonzalez-Perez RR, Lanier V, Newman G. Leptin's Pro-Angiogenic Signature in Breast Cancer. Cancers (Basel) 2013; 5: 1140-62.

40. Newman G, Gonzalez-Perez RR. Leptin-cytokine crosstalk in breast cancer. Mol Cell Endocrinol 2014; 382: 570-82.

41. Mantzoros CS, Bolhke K, Moschos S, Cramer CS. Leptin in relation to carcinoma in situ of the breast: a study of pre-menopausal cases and controls. Int J Cancer 1999; 80: 523-6.

42. Coskun U, Gunel N, Toruner FB, Sancak B, Onuk E, Bayram O. Serum leptin, prolactin and vascular endothelial growth factor (VEGF) levels in patients with breast cancer. Neoplasma 2003; 50: 41-6.

43. Sauter ER, Garofalo C, Hewett J, Hewett JE, Morelli C, Surmacz E. Leptin expression in breast nipple aspirate fluid (NAF) and serum is influenced by body mass index (BMI) but not by the presence of breast cancer. Horm Metab Res 2004; 36: 336-40.

44. Stattin P, Soderberg S, Biessy C, Lenner P, Hallmans G, Kaaka R, Olsson T. Plasma leptin and breast cancer risk: a prospective study in northern Sweden. Breast Cancer Res Treat 2004; 86: 191-6.
45. Woo HY, Park H, Ki CS, Park YL, Bae WG. Relationships among serum leptin, leptin receptor gene polymorphisms, and breast cancer in Korea. Cancer Lett 2006; 237: 137-42.

46. Samy N, Ragab HM, El Maksoud NA, Shaalan M. Prognostic significance of serum Her2/neu, BCL2, CA15-3 and CEA in breast cancer patients: a short follow-up. Cancer Biomark 2010; 6: 63-72

47. Hashim ZM. The significance of CA15-3 in breast cancer patients and its relationship to HER-2 receptor status. Int J Immunopathol Pharmacol 2014; 27: 45-51.

48. Paracchini V, Pedotti P, Taioli E. Genetics of leptin and obesity: a HuGE review. Am J Epidemiol 2005; 162: 101-14.

49. Mattevi VS, Zembrzuski VM, Hutz MH. Association analysis of genes involved in the leptinsignaling pathway with obesity in Brazil. Int J Obes Relat Metab Disord 2002; 26: 1179-85.

50. Snoussi K, Strosberg AD, Bouaouina N, Ahmed SB, Helal AN Chouchane L. Leptin and leptin receptor polymorphisms are associated with increased risk and poor prognosis of breast carcinoma. BMC Cancer 2006; 6: 38-51.

51. Anuradha C, Ranjit PM, Surekha D, Raghunadharao D, Rani NS, Vishnupriy S. Association of leptin receptor (LEPR) Q223R polymorphism with breast cancer. Global J Med Res 2012; 12: 20-30.

52. Woo HY, Park H, Ki CS, Park YL, Bae WG. Relationships among serum leptin, leptin receptor gene polymorphisms, and breast cancer in Korea. Cancer Lett 2005; 9: 1-6.

53. Nakahara K, Okame R, Katayama T, Miyazato M, Kangawa K, Murakami N. Nutritional and environmental factors affecting plasma ghrelin and leptin levels in rats. J Endocrinol 2010; 207: 95-103.

54. Mahmoudi R, Noori Alavicheh B, Nazer Mozaffari MA, Fararouei M, Nikseresht M. Polymorphisms of leptin (-2548 G/A) and leptin receptor (Q223R) genes in Iranian women with breast cancer. Int Genomics 2015; 2015: 132720.

\section{Address for correspondence}

\section{Dr. Dalia Shaheen, Assoc. Prof}

Faculty of Medicine

Mansoura University

Mansoura, Egypt

e-mail: daliashaheen72@yahoo.com

Submitted: 14.09 .2016

Accepted: $\quad 29.01 .2017$ 